\title{
LC-MS/MS Tandem Mass Spectrometry for Analysis of Phenolic Compounds and Pentacyclic Triterpenes in Antifungal Extracts of Terminalia brownii (Fresen)
}

\author{
Enass Y. A. Salih ${ }^{1,3,4, *}$, Pia Fyhrquist ${ }^{3}$, Ashraf M. A. Abdalla ${ }^{1}$, Abdelazim Y. Abdelgadir ${ }^{1}$, \\ Markku Kanninen ${ }^{4}$, Marketta Sipi ${ }^{4}$, Olavi Luukkanen ${ }^{4}$, Mustafa K. M. Fahmi ${ }^{1,4}$, \\ Mai H. Elamin ${ }^{5}$ and Hiba A. Ali ${ }^{2,+}$ \\ 1 Department of Forest Products and Industries, Faculty of Forestry, PO Box 13314, University of Khartoum, \\ Khartoum 11111, Sudan; amahmed@uofk.edu (A.M.A.A.); ayabdelgadir@uofk.edu (A.Y.A.); \\ mkfahmi@uofk.edu (M.K.M.F.) \\ 2 Commission for Biotechnology and Genetic Engineering, PO Box 2404, National Centre for Research, \\ Khartoum, Sudan; hibaali@hotmail.com \\ 3 Faculty of Pharmacy, Division of Pharmaceutical Biosciences, PO Box 56, University of Helsinki, \\ FIN-00014 Helsinki, Finland; pia.fyhrquist@helsinki.fi \\ 4 Viikki Tropical Resources Institute (VITRI), Department of Forest Sciences, PO Box 27, \\ University of Helsinki, FIN-00014 Helsinki, Finland; markku.kanninen@helsinki.fi (M.K.); \\ Marketta.Sipi@helsinki.fi (M.S.); olavi.luukkanen@helsinki.fi (O.L.) \\ 5 Department of Phytochemistry, Faculty of Pharmacy, PO Box 477, University of Sciences and Technology, \\ Omdurman, Sudan; maielamin15@gmail.com \\ * Correspondence: enass.salih@helsinki.fi or eyabdelkareem@uofk.edu; Tel.: +358-46-9356-095 \\ $+\quad$ With this paper we would like to honor our colleague, Dr. Hiba Ali, who passed away the 29.4.2016.
}

Academic Editor: Leonard Amaral

Received: 30 October 2017; Accepted: 7 December 2017; Published: 13 December 2017

\begin{abstract}
Decoctions and macerations of the stem bark and wood of Terminalia brownii Fresen. are used in traditional medicine for fungal infections and as fungicides on field crops and in traditional granaries in Sudan. In addition, T. brownii water extracts are commonly used as sprays for protecting wooden houses and furniture. Therefore, using agar disc diffusion and macrodilution methods, eight extracts of various polarities from the stem wood and bark were screened for their growth-inhibitory effects against filamentous fungi commonly causing fruit, vegetable, grain and wood decay, as well as infections in the immunocompromised host. Ethyl acetate extracts of the stem wood and bark gave the best antifungal activities, with MIC values of $250 \mu \mathrm{g} / \mathrm{mL}$ against Nattrassia mangiferae and Fusarium verticillioides, and $500 \mu \mathrm{g} / \mathrm{mL}$ against Aspergillus niger and Aspergillus flavus. Aqueous extracts gave almost as potent effects as the ethyl acetate extracts against the Aspergillus and Fusarium strains, and were slightly more active than the ethyl acetate extracts against Nattrassia mangiferae. Thin layer chromatography, RP-HPLC-DAD and tandem mass spectrometry (LC-MS/MS), were employed to identify the chemical constituents in the ethyl acetate fractions of the stem bark and wood. The stem bark and wood were found to have a similar qualitative composition of polyphenols and triterpenoids, but differed quantitatively from each other. The stilbene derivatives, cis- (3) and trans- resveratrol-3-O- $\beta$-galloylglucoside (4), were identified for the first time in T. brownii. Moreover, methyl-(S)-flavogallonate (5), quercetin-7- $\beta$-O-di-glucoside (8), quercetin-7-O-galloyl-glucoside (10), naringenin-4'-methoxy-7-pyranoside (7), 5,6-dihydroxy-3', $4^{\prime}, 7$-tri-methoxy flavone (12), gallagic acid dilactone (terminalin) (6), a corilagin derivative (9) and two oleanane type triterpenoids (1) and (2) were characterized. The flavonoids, a corilagin derivative and terminalin, have not been identified before in T. brownii. We reported earlier on the occurrence of methyl-S-flavogallonate and its isomer in the roots of T. brownii, but this is the first report on their occurrence in the stem wood as well. Our results justify the traditional uses of macerations and decoctions of T. brownii stem wood and
\end{abstract}


bark for crop and wood protection and demonstrate that standardized extracts could have uses for the eco-friendly control of plant pathogenic fungi in African agroforestry systems. Likewise, our results justify the traditional uses of these preparations for the treatment of skin infections caused by filamentous fungi.

Keywords: Africa; Terminalia brownii; antifungal stem wood and bark extracts; Aspergillus; Nattrassia; Fusarium; LC-MS/MS; flavonoids; ellagitannins; stilbenes; triterpenes

\section{Introduction}

Fungal contamination is both a pre- and a post-harvesting problem in crop production and poses a continuous and growing threat to global food crop production [1,2]. Some of the fungal species generally considered to be phytopathogens, such as Aspergillus spp., are also known to be increasingly significant as human pathogens, especially in the immunocompromised host [3-5].

Aspergillus niger (van Tieghem, 1867) and Aspergillus flavus (Link, 1809) are both human [6,7] and plant pathogens [8]. As human pathogens, especially A. flavus, but also A. niger cause aspergillosis in immunocompromised individuals $[9,10]$. A. flavus causes grain crop infections in maize (Zea mays L.), leading to a substantial decrease in the commercial value of maize crop due to aflatoxin contamination [11]. Moreover, A. flavus is often the causative agent of wood decay in timber and houses [12]. Nattrassia mangiferae [(Syd. and P. Syd.) B. Sutton and Dyko], previously known as Hendersonula toruloi Nattrass (HT) and Dothiorella mangiferae (Syd. and P. Syd), is a wound-invading dematiaceous (brown-pigmented) phytopathogenic fungus infecting hard wood species of Citrus, Mangifera and Eucalyptus and soft wood coniferous subtropical and tropical trees, causing dieback and vascular wilt diseases $[13,14]$. Nattrassia mangiferae is also a human pathogenic fungus, especially in immunocompromised individuals [15], and is even known to cause community acquired infections in rural farmer societies worldwide [13]. Fusarium verticilloides and some other Fusarium species infect maize ears (husks) causing maize ear rot disease and contaminate maize grains with fumonisin mycotoxins leading to major pre- and post-harvest losses [16]. Fusarium spp. mycotoxins are toxic [17,18], and fumonisin has been found to cause cancer in mammalians [19]. Another species of Fusarium, F. oxysporum is the causative agent of the "Panama disease" affecting the banana (Musa paradisiaca), the staple food of a large part of Africa.

Currently used fungicides are costly and toxic to the environment [20,21]. Besides, phytopathogenic and human pathogenic filamentous fungi have developed resistance to many conventional fungicides and to antibiotics [22-26]. Thus, new effective, less toxic, affordable and readily available antifungals are needed [26]. Tropical and subtropical plants are known to contain a wide range of defense compounds due to their needs for constant production of defense compounds throughout the year as well as due to the high biodiversity in rain forests, woodlands and savannahs [27]. Thus, tropical plant species used for fungal infections in African traditional medicine as well as for protection of crop plants against fungal contamination, are expected to be good sources for new antifungal compounds [28,29].

The pantropical genus of Terminalia (Combretaceae) contains a number of species known for their antifungal effects. Antifungal activities against Aspergillus niger and A. flavus have been reported for the Asian species, Terminalia alata, T. arjuna, T. bellerica, T. catappa and T. chebula [30,31]. Approximately 30 species of Terminalia occur in Africa [32]. However, despite of their frequent uses in traditional medicine for treatment of fungal infections in humans and in traditional agriculture for prevention of fungal crop plant contamination, only a small portion of these species have been studied in depth for their antifungal activity and/or antifungal compounds. Among those African Terminalia species investigated for their antifungal potential, either against yeasts or filamentous fungi or both, are T. avicennoides, T. spinosa, T. sericea and T. nigrovenulosa [33-36]. Ellagitannins, ellagic acid derivatives, stilbenes, lignans, flavonoids and pentacyclic triterpenes were reported from some 
African species of Terminalia, such as T. horrida, T. sericea, T. superba and T. macroptera [33,34,37-45]. Most of these phytochemical investigations did not include antifungal screening of the characterized compounds, however.

Terminalia brownii (Fresen.) is a deciduous tree distributed throughout East African savannah regions in a wide range of temperature, rain fall and soil conditions (Figure 1) [46]. In Sudan, T. brownii occurs in low and high rainfall zones in Blue Nile state and El-Gadarif in the eastern part of the country and Kordofan and Darfour states in the western part of Sudan. In Sudan, T. brownii grows in natural forested areas such as savannah woodlands where it is listed as an endangered species due to overexploitation [47]. T brownii has been found to be exceptionally resistant against various pathogenic fungi that affect crops, and is frequently used in traditional agroforestry for crop plant protection [21]. Similarly to many other plant species, such as Melianthus comosus [48], also decoctions of various parts of $T$. brownii have traditional applications as fungicides against fungal contamination in harvested crop plants.

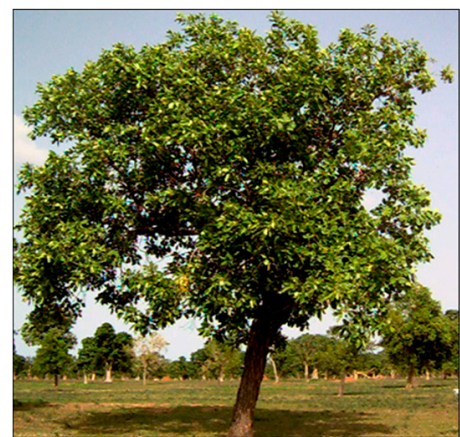

(A)

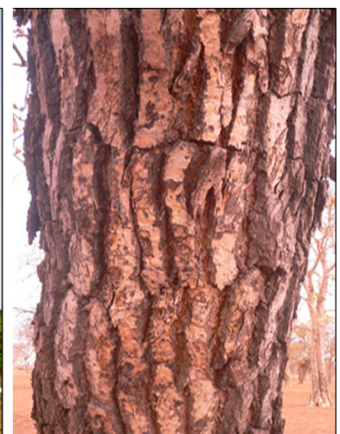

(B)

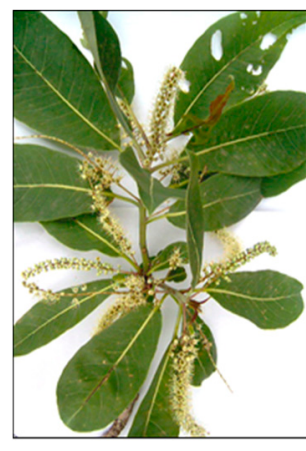

(C)

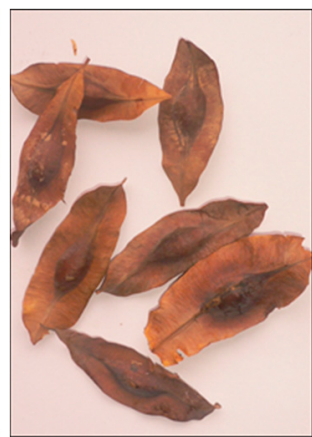

(D)

Figure 1. Terminalia brownii. (A) tree in savannah woodland; (B) stem bark; (C) flowers and leaves; (D) fruits. Photo: E. Y. A. Salih and Dr. H. H. Gibreel, 2006.

Terminalia brownii has been found to be a rich source of oleanane- and ursane-type pentacyclic triterpenoids, such as arjunic acid, galloyl arjunic acid, tomentosic acid, sericic acid, arjungenin, sericoside, betulinic acid, monogynol $\mathrm{A}$ and arjunglucoside [21,49]. In addition, a new oleanane type triterpenoid, designated as $3 \beta, 24$-O-ethylidenyl-2 $\alpha, 19 \alpha$-dihydroxyolean-12-en-28-oic acid, was identified in an ethyl acetate extract of the stem bark of T. brownii [49]. Moreover, $\beta$-sitosterol and ellagic acid derivatives have been characterized from the leaves and stem bark of T. brownii [21,49]. In addition, a number of unknown and known ellagitannins, including methyl-(S)-flavogallonate and its derivative as well as $\alpha, \beta$-punicalagin and $\alpha, \beta$-terchebulin have been described form the roots and the stem bark, respectively [50,51]. Moreover, a chromone derivative designated as terminalianone has been found in the stem bark of T. brownii [52]. However, to our knowledge, the antifungal effects of the mentioned compounds were not investigated, with the exception of arjungenin, $\beta$-sitosterol and betulinic acid [21].

Although T. brownii extracts are used traditionally against fungal phytopathogens and to treat human fungal infections in Sudan and in other countries of Africa, there are a limited number of reports on their in vitro antifungal activity against filamentous fungi affecting crop production and human health. Moreover, only a small number of antifungal compounds in T. brownii have been characterized to date [21,49], and to the best of our knowledge, no flavonoid structures have been studied in this species of Terminalia. Therefore, the current study was performed to verify the antifungal effects of decoctions and macerations, reported to be used for fungal infections in traditional medicine and as fungicides in traditional agriculture. In addition, extracts of various polarities made from the stem bark and wood of T. brownii were tested for their growth-inhibitory effects. For the screenings, significant phytopathogenic and human pathogenic opportunistic fungi of the genera Aspergillus, Nattrassia and 
Fusarium were used. Thin layer chromatography (TLC) and RP-HPLC/DAD were used to study the phytochemical composition of the ethyl acetate extracts of the stem wood and bark. Tandem mass spectrometry (LC-MS/MS) was used to elucidate the molecular masses of flavonoids, triterpenes, ellagitannins and stilbenes in an antifungal stem wood extract of T. brownii.

\section{Results}

\subsection{Antifungal Effects of Extracts of Terminalia brownii Stem Bark and Wood}

The results of the growth inhibition of various extracts of Terminalia brownii stem bark and wood against Aspergillus, Nattrassia and Fusarium strains are shown in Table 1. When compared to the other extracts, the ethyl acetate extracts of the stem wood and bark gave the highest antifungal activity. This result is in accordance with other authors, who also reported that especially ethyl acetate extracts of the stem bark of T. brownii give good antifungal effects against sweet potato infecting fungi, such as Aspergillus niger and Fusarium solanii [21]. The reference antifungal used in our tests, amphotericin-B, was more growth-inhibitory than the ethyl acetate extracts, however, although the differences in potency between amphotericin-B and the ethyl acetate extracts were not big, considering that we used plant extracts instead of pure compounds present in these extracts (Table 1).

Our results demonstrate that Nattrassia mangiferae and Fusarium verticilliodies were especially sensitive to the ethyl acetate extracts of T. brownii stem wood and bark, giving MIC values of $250 \mu \mathrm{g} / \mathrm{mL}$, whereas Aspergillus niger and A. flavus were more resistant to these extracts, demonstrating MIC values of $500 \mu \mathrm{g} / \mathrm{mL}$ (Table 1). We found that the obtained MIC values correlated well with the sizes of the inhibition zones produced by these ethyl acetate extracts, so that small MIC values were coupled to large diameters of the inhibition zones (Table 1). To the best of our knowledge, this is the first report on antifungal effects of T. brownii against Nattrassia mangiferae.

Interestingly, we also found that aqueous extracts of the stem bark and wood of T. brownii gave good growth-inhibitory effects (Table 1). Compared to the other extracts these aqueous extracts gave especially high extraction yields of 20 and 16\%, respectively for bark and wood (Figure 2). Thus, our results justify the traditional application of macerations (water extracts) of the stem wood and barks of T. brownii for the preservation of grains and wooden house poles and for traditional medicinal treatment of fungal infections caused by Aspergillus, Nattrassia and Fusarium. Earlier studies have indicated that aqueous stem bark extracts of T. brownii are growth-inhibitory also against yeast species, such as Candida albicans and Cryprococcus neoformans and in addition the aqueous extracts were found to be less toxic than other extracts against brine shrimps [53]. Thus, standardized aqueous extracts of T. brownii stem wood and bark could be used to treat fungal infections and fungal contamination.

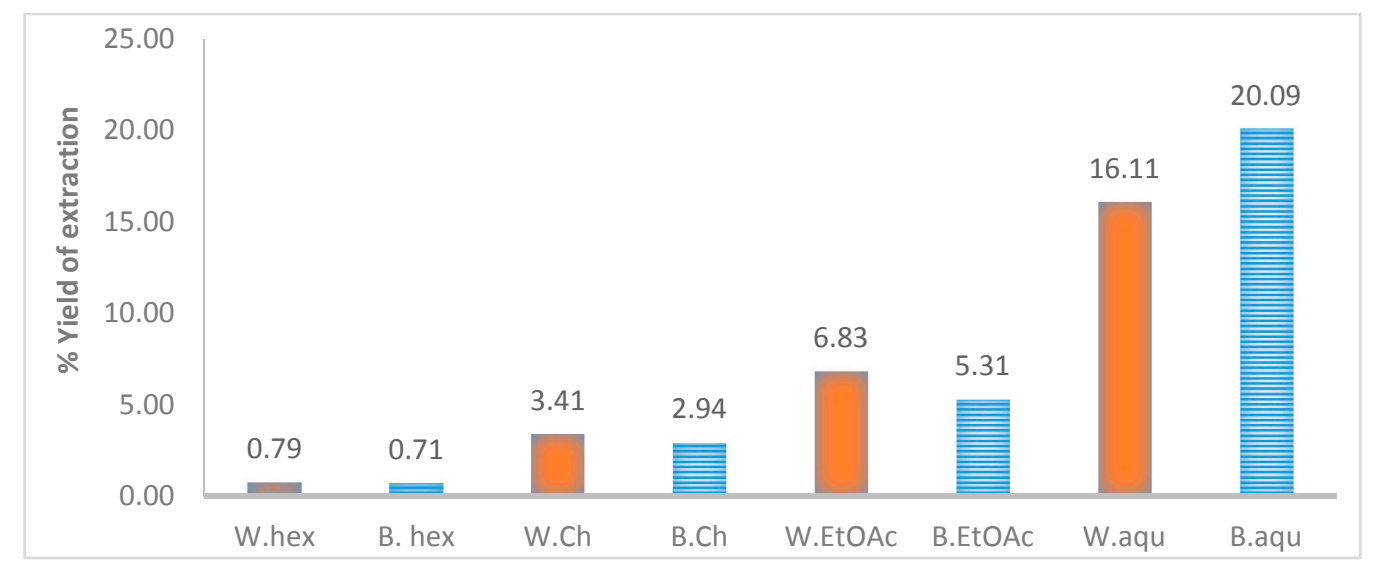

Figure 2. Percentage yield $(\% w / w)$ resulting from sequential extraction and liquid/liquid partition of the stem wood and stem bark of Terminalia brownii. W, stem wood; B, stem bark; hex, hexane extract; $\mathrm{Ch}$, choloroform extract; EtOAc, ethyl acetate extract; aqu, aqueous extract. 
When compared to the more polar water and ethyl acetate extracts, we found that chloroform extracts of the stem wood and bark of T. brownii were slightly antifungal, while the petroleum ether extracts were devoid of antifungal activity (Table 1). In contrast to our results, in an earlier investigation, it was found that an n-hexane extract of the stem bark of Terminalia brownii was active against another Aspergillus species, A. fumigatus [54]. Perhaps this result might indicate that different species of Aspergillus differ to their sensitivity to non-polar extracts of T. brownii, so that $A$. fumigatus is more sensitive than $A$. niger and $A$. flavus.

Table 1. Antifungal activity of stem wood and bark extracts of T. brownii. Results were obtained using cup well agar diffusion and agar dilution methods.

\begin{tabular}{|c|c|c|c|c|c|c|}
\hline \multirow{2}{*}{ Fungal Strain } & \multicolumn{2}{|c|}{ Stem Wood Extracts } & \multicolumn{2}{|c|}{ Stem Bark Extracts } & \multicolumn{2}{|c|}{ Amphotericin-B } \\
\hline & IZ & MIC & IZ & MIC & IZ & MIC \\
\hline \multicolumn{7}{|l|}{ Aspergillus niger } \\
\hline $\begin{array}{c}\mathrm{Pt} \\
\mathrm{CHCl} 3 \\
\text { EtOAc } \\
\text { aqueous } \\
\text { Aspergillus flavus } \\
\end{array}$ & $\begin{array}{l}\text { NA } \\
12 \pm 0.9 \\
17 \pm 0.7 \\
17 \pm 0.5\end{array}$ & 500 & $\begin{array}{l}\text { NA } \\
13 \pm 0.4 \\
17 \pm 0.8 \\
16.5 \pm 0.4\end{array}$ & 500 & $35 \pm 0.01$ & 31.25 \\
\hline $\begin{array}{c}\mathrm{Pt} \\
\mathrm{CHCl} 3 \\
\text { EtOAc } \\
\text { aqueous } \\
\text { Nattrassia mangiferae }\end{array}$ & $\begin{array}{l}\text { NA } \\
14 \pm 0.5 \\
18.5 \pm 0.4 \\
18 \pm 0.9\end{array}$ & 500 & $\begin{array}{l}\text { NA } \\
14 \pm 0.9 \\
18.5 \pm 0.8 \\
18 \pm 0.5\end{array}$ & 500 & $28 \pm 0.03$ & 125 \\
\hline $\begin{array}{c}\mathrm{Pt} \\
\mathrm{CHCl} 3 \\
\text { EtOAc } \\
\text { aqueous } \\
\text { Fusarium verticillioides } \\
\end{array}$ & $\begin{array}{l}\text { NA } \\
12 \pm 0.5 \\
19 \pm 0.4 \\
18.5 \pm 0.4\end{array}$ & 250 & $\begin{array}{l}\text { NA } \\
12 \pm 0.7 \\
18.5 \pm 0.4 \\
19 \pm 0.4\end{array}$ & 250 & $30 \pm 0.04$ & 62.5 \\
\hline $\begin{array}{c}\mathrm{Pt} \\
\mathrm{CHCl} 3 \\
\text { EtOAc } \\
\text { aqueous }\end{array}$ & $\begin{array}{l}\text { NA } \\
13 \pm 0.6 \\
20 \pm 0.4 \\
19 \pm 0.3\end{array}$ & 250 & $\begin{array}{l}\text { NA } \\
11 \pm 0.9 \\
19 \pm 0.2 \\
18 \pm 0.7\end{array}$ & 250 & $31 \pm 0.03$ & 62.5 \\
\hline
\end{tabular}

For agar diffusion, extracts at the concentration $1 \mathrm{mg} / \mathrm{mL}$ were used. Diameter of inhibition zones (IZ) in mm: $>18 \mathrm{~mm}$ : sensitive; 14-18 mm: intermediate; <14 mm: resistant [55,56]; Pt, petroleum ether extracts; CHCL3, chloroform extracts; EtOAc, ethyl acetate extracts; NA, Not active. IZ results as mean \pm SEM of five measurements. $\mathrm{MIC}$ in $\mu \mathrm{g} / \mathrm{mL}$. The observed differences between the sample means of the inhibition zones (the stem bark and wood extracts) against the tested fungi did not differ significantly.

\subsection{Results from the Phytochemical Screening of Antifungal Ethyl Acetate Extracts of T. brownii Stem Wood and Bark}

Owing to our promising antifungal results for the ethyl acetate extracts of the stem bark and wood of $T$. brownii, and to the few existing earlier records on the activity of this species against filamentous fungi, we investigated the secondary compound composition and molecular masses as well as the fragmentation patterns of phenolic compounds and triterpenoids of these extracts.

\subsubsection{TLC Results}

RP-18 thin layer chromatograms of the ethyl acetate extracts of the stem wood and stem bark of $T$. brownii gave a negative reaction with Dragendorff reagent, suggesting that these extracts were devoid of alkaloids. Pink to purple colors were developed upon spraying with vanillin- $\mathrm{H}_{2} \mathrm{SO}_{4}$, which suggested the presence of triterpenoid and phenolic compounds. Spraying the TLC plates with aluminum trichloride $\left(\mathrm{AlCl}_{3}\right)$ and Natural Product reagent (NPR), revealed the presence of flavonoids, since color changes from quenching fluorescence to yellow, orange or blue color, typical for flavonoidal acids or other phenolic acids, could be observed at $366 \mathrm{~nm}$ [57]. 


\subsubsection{HPLC-UV/DAD Results}

HPLC-UV/DAD fingerprints of the ethyl acetate extracts of the stem bark and stem wood of Terminalia brownii are presented in Figure 3. Altogether twelve compounds with retention times between 6.8 and 25.5 min could be identified using internal standards and a computer library for standard compounds. At the wavelengths of 320 and $254 \mathrm{~nm}$, which were used for detection of stilbenes and flavonoids, the wood ethyl acetate extract displayed a higher diversity of flavonoidal and stilbenoid compounds. For example, the cis- and trans-isomers of resveratrol 3-O- $\beta$-galloyl-glucoside (3 and 4 ) at Rt 11.1 and $13.2 \mathrm{~min}$, respectively, as well as naringenin-4'-methoxy-7-pyranoside (7) at $15.3 \mathrm{~min}$, the corilagin derivative (9) at Rt $18.2 \mathrm{~min}$, and quercetin-7-O-galloyl glucoside (10) at Rt $18.4 \mathrm{~min}$, were present in the wood extract but absent from the stem bark extract as shown in Figure 3.

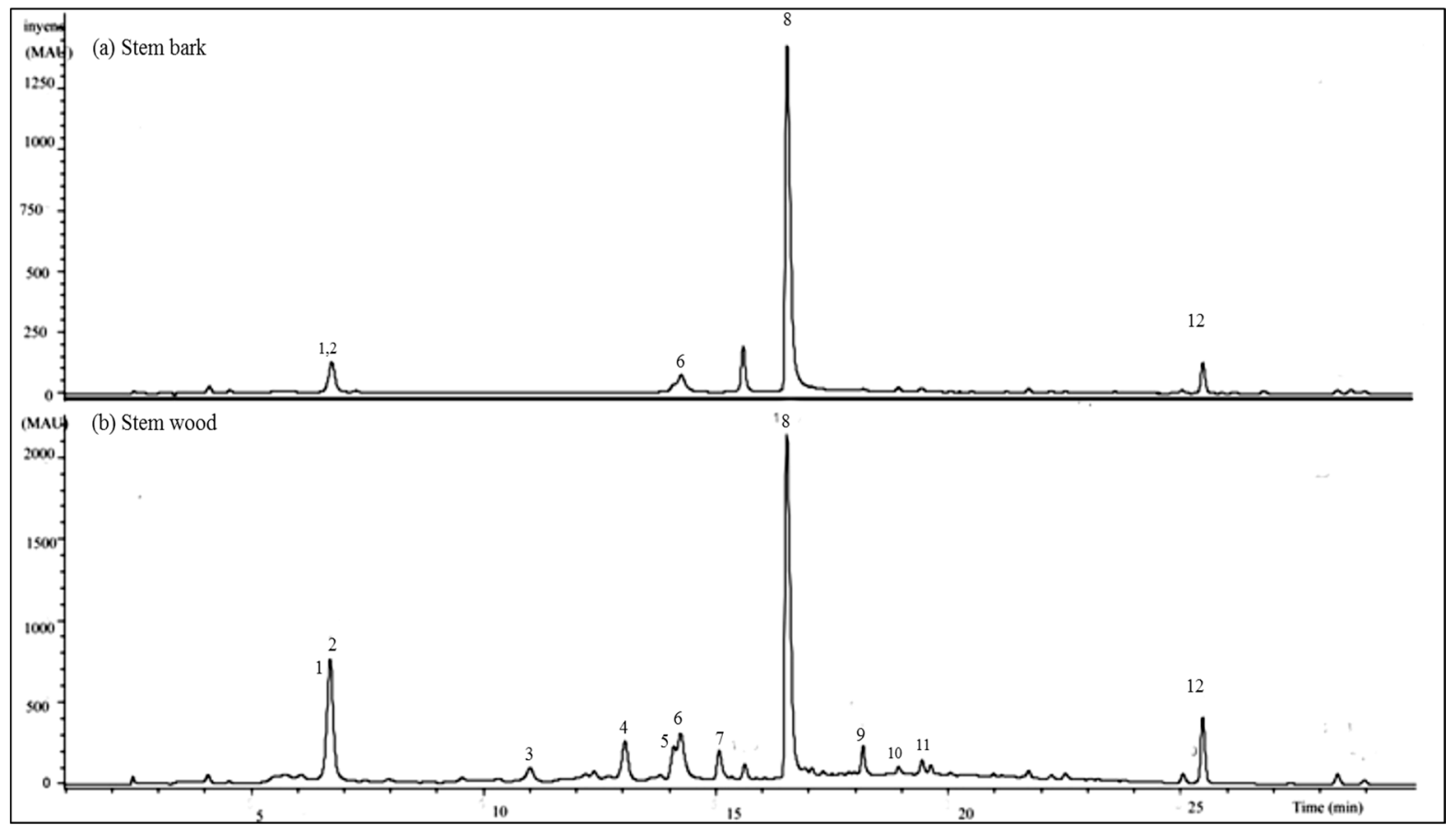

Figure 3. RP-HPLC/DAD chromatograms of ethyl acetate extracts of T.brownii. (A) stem bark and (B) stem wood extracts at $254 \mathrm{~nm}$. (1) and (2) Oleanane type triterpenoids; (3) cis-resveratrol-3-O$\beta$-galloyl-glucoside; (4) trans-resveratrol-3-O- $\beta$-galloyl-glucoside; (5) Methyl-(S)-flavogallonate; (6) Gallagic acid dilactone (Terminalin); (7) Naringenin-4'-methoxy-7-pyranoside; (8) Quercetin-7-ß-Odiglucoside; (9) Corilagin derivative; (10) Quercetin-7-O-galloyl-glucoside; (11) unknown ellagitannin; (12) 5,6-dihydroxy-3', 4',7-trimethoxy flavone.

Because of the high number of compounds present in the wood ethyl acetate extract and due to this extract being slightly more antifungal than the stem bark, at least in terms of the sizes of the diameters of inhibition zones (Table 1), this extract was subjected to LC-MS/MS advanced analysis for identification of the major compounds.

\subsubsection{LC-MS/MS Results}

MS/MS combined with collision-induced dissociation (CID), has been found to enable the accurate identification of stilbenes and flavonoids in complex extracts with co-eluting peaks [58]. Therefore MS/MS was employed as the method of choice for the identification of compounds in an ethyl acetate extract of T. brownii stem wood. A total of twelve compounds were characterized by comparing the obtained molecular (precursor) ions and fragmentation patterns (i.e., product ions) from our LC-MS/MS data with data from the literature and with a computer library for the standard compounds 
(Table 2). The $\mathrm{MS}^{2}, \mathrm{MS}^{3}$ and MS 4 ion chromatograms are presented in the supplemental part of this paper (Supplement 1).

Table 2. HPLC-DAD and MS/MS data of phenolic compounds and triterpenoids in an ethyl acetate extract of the stem wood of T. brownii.

\begin{tabular}{|c|c|c|c|c|c|c|}
\hline Peak No & Rt (min) & $\begin{array}{c}{[\mathrm{M}-\mathrm{H}]} \\
(m / z)\end{array}$ & $\begin{array}{c}\text { CID } \mathbf{M}^{\mathrm{n}} \\
\text { Main Fragment } \\
\text { Ions }(\mathrm{m} / \mathrm{z})\end{array}$ & Identified Compound & $\begin{array}{l}\text { Molecular } \\
\text { Formula }\end{array}$ & $\begin{array}{l}\text { Exact Mass } \\
\text { (Calc.) }\end{array}$ \\
\hline 1 & 6.8 & 469 & $\begin{array}{c}425,407,379,353 \\
300,271\end{array}$ & oleanane type triterpenoid & - & - \\
\hline 2 & 6.8 & 491 & $\begin{array}{c}447,429,411,401 \\
385,301\end{array}$ & oleanane type triterpenoid & - & - \\
\hline 3 & 11.1 & 541 & $\begin{array}{l}532,425,397,301, \\
273,227,199,169\end{array}$ & cis-resveratrol-3-O- $\beta$-galloyl-glucoside & $\mathrm{C}_{27} \mathrm{H}_{26} \mathrm{O}_{12}$ & 542.1416 \\
\hline 4 & 13.2 & 541 & $\begin{array}{l}532,424,407,300 \\
275, \underline{227}, 199,169\end{array}$ & trans-resveratrol-3-O- $\beta$-galloyl-glucoside & $\mathrm{C}_{27} \mathrm{H}_{26} \mathrm{O}_{12}$ & 542.1416 \\
\hline 5 & 14.1 & 483 & $\begin{array}{c}451,433,407,305 \\
405,377\end{array}$ & Methyl-(S)-flavogallonate & $\mathrm{C}_{22} \mathrm{H}_{12} \mathrm{O}_{13}$ & 484.0273 \\
\hline 6 & 14.4 & 601 & $\begin{array}{c}583,301,299,271 \\
243,215\end{array}$ & Gallagic acid dilactone & $\mathrm{C}_{28} \mathrm{H}_{10} \mathrm{O}_{16}$ & 601.9964 \\
\hline 7 & 15.3 & 433 & $\begin{array}{c}300,314,229,271 \\
132\end{array}$ & Naringenin-4'-methoxy-7-pyranoside & - & - \\
\hline 8 & 16.8 & 625 & $\begin{array}{c}301,284,256,229 \\
201,185,129\end{array}$ & Quercetin-7- $\beta$-O-diglucoside & $\mathrm{C}_{27} \mathrm{H}_{30} \mathrm{O}_{17}$ & 626.1473 \\
\hline 9 & 18.2 & 633 & $\begin{array}{l}481,463,421,387 \\
305,275,300,169\end{array}$ & Corilagin derivative & - & - \\
\hline 10 & 18.4 & 585 & $\begin{array}{l}\underline{301}, 284,257,229 \\
201,185,153,132\end{array}$ & Quercetin-7-O-galloyl-glucoside & - & - \\
\hline 11 & 19.1 & 725 & $\begin{array}{c}665,503,409,441 \\
379,391\end{array}$ & Unknown ellagitannin & - & - \\
\hline 12 & 25.5 & 343 & $\begin{array}{c}328,313,298,285 \\
270,257\end{array}$ & 5,6-dihydroxy-3', $4^{\prime}, 7$-trimethoxy-flavone & - & - \\
\hline
\end{tabular}

$\mathrm{Rt}$, retention time in HPLC-DAD; [M-H ] ${ }^{-}(\mathrm{m} / \mathrm{z})$, base or molecular ions at negative mode; CID $\mathrm{M}^{\mathrm{n}}$, Fragmentation ions resulting from collision-induced dissociation; The exact mass (calc.) according to the molecular formula of identified compounds. Aglycones are underlined. Peak numbers according to Figure 3.

We found that the stem wood of T. brownii contains two oleanane triterpenoid acids that co-eluted at $6.8 \mathrm{~min}$ (Figures 3 and 4). For compound (1) a [M-H] $]^{-}$molecular ion at $m / z 469$ was detected, whereas compound (2) gave a molecular ion of $m / z$ 491. In the $\mathrm{MS}^{2}$ chromatograms, a fragment ion at $m / z 425$ was detected for compound (1) and at $m / z 447$ for compound (2) (Table 2, Supplement 1 , Slide 1). These fragment ions indicate the loss of a carboxylic acid (-COOH) group ([M-H $]^{-}$for $-\mathrm{COOH}=44)$ from both molecular ions. In agreement with our results, the loss of carboxylic acid at position 17 in pentacyclic triterpenoids was observed when using atmospheric pressure chemical ionization (APCI)-MS [59,60]. Moreover, we observed a fragment ion at $m / z 407$, which indicated the loss of $\mathrm{H}_{2} \mathrm{O}$ from $m / z 425$ in compound 1 . This kind of mass spectral fragmentation pattern is typical for oleanane type triterpenes $[61,62]$, therefore confirming that compounds 1 and 2 are oleanane type triterpenes (Figure 4A).

In our HPLC-DAD system, compounds (3) and (4) eluted at Rt 11.1 and $13.2 \mathrm{~min}$, respectively (Figure 3b). Both compounds showed an identical $[\mathrm{M}-\mathrm{H}]^{-}$molecular ion at $m / z 541$. Moreover, when subjected to $\mathrm{MS}^{3}$, both compounds provided fragment ions of $m / z 227$ and 314 (Table 2, Supplement 1 , Slide 3 and 4). The fragment ion at $m / z 314$ indicates the presence of a galloylhexose fragment [63]. A comparison with the literature showed that the fragment ion at $m / z 227$ corresponds to the resveratrol unit [44]. Therefore, compounds (3) and (4) were tentatively assigned as resveratrol-3-O- $\beta$-galloyl-glucoside, respectively. Due to different retention times, the compounds were proposed to be cis- (3) and trans- (4) isomers of resveratrol-3-O- $\beta$-galloylglucoside (Figure 4C). 


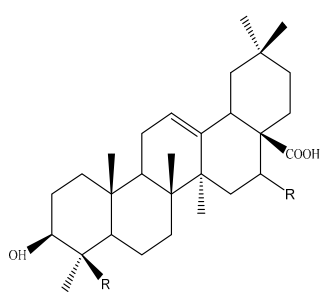

(A) Oleanolic acid triterpenoids

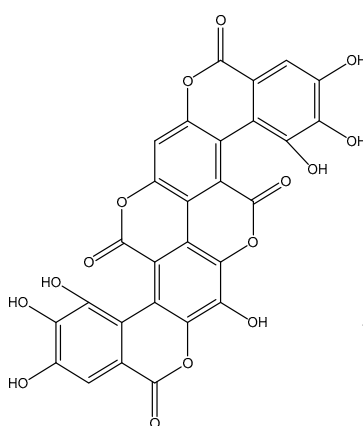

(B) Terminalin (gallagic acid dilactone)

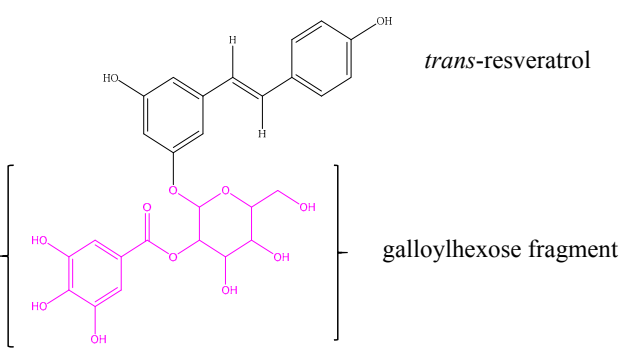

(C) trans-resveratrol-3- $O$ - $\beta$-galloyl-glucoside

Figure 4. Chemical structures of some of the characterized compounds in the stem wood and stem bark of T. brownii. (A) oleanane type triterpenoids (compounds $\mathbf{1}$ and 2); (B) Terminalin (compound 6) and $(\mathbf{C})$ trans-resveratrol-3-O- $\beta$-galloyl-glucoside (compound 4).

When subjected to $\mathrm{MS}^{2}$, compound (5) at Rt $14.1 \mathrm{~min}$ in HPLC-DAD (Figure 3b), gave an [M-H] $]^{-}$molecular ion at $m / z 483$ (Table 2, Supplement 1, Slide 5). The loss of the two oxygen molecules $\{483-451=32\}$ at $\mathrm{MS}^{3}$, gave a fragmentation ion at $m / z 433$. Also, the $\mathrm{MS}^{3}$ spectrum was devoid of the fragment of [M-H- $\left.-\mathrm{CO}_{2}\right]^{-}$, which corresponds to a methyl ester molecule [64]. Therefore, and according to previous investigations [45,50], compound (5) was tentatively assigned the structure of methyl-(S)-flavogallonate.

Compound (6) at Rt 14.4 min (Figure 3b), gave a [M-H] $]^{-}$molecular ion at $m / z 601$ (Figure $3 b$, Table 2). When subjected to $\mathrm{MS}^{3}$, compound (6) yielded the fragment ions at $m / z 271$ and 301, the later corresponding to free ellagic acid (Supplement 1, Slide 6). A molecular ion of $\mathrm{m} / z 601$ and fragment ions at $m / z 271$ and 301 have been reported for gallagic acid [45]. Gallagic acid dilactone (syn. terminalin) has been reported in another species of Terminalia, T. oblongata [65]. Accordingly, compound (6) was tentatively assigned the structure of gallagic acid dilactone (terminalin) (Figure 4B).

Compound (7) at Rt 15.3 min (Figure 3b) gave an $[\mathrm{M}-\mathrm{H}]^{-}$molecular ion at $m / z 433$ (Table 2). The deprotonation of $[\mathrm{M}-\mathrm{H}]^{-}$at $\mathrm{MS}^{2}$ resulted in a fragment ion at $m / z 300$, indicating the loss of one molecule of a pentose sugar ([M-H]-132) [63,66]. Moreover, $\mathrm{MS}^{3}$ of this compound yielded the loss of an $Y 0$ fragment at $m / z 271$, corresponding to the cleavage of the aglycone fragment ion of the flavanone naringenin [66-68]. In the $\mathrm{MS}^{3}$, the $[\mathrm{M}-\mathrm{H}]^{-}$yielded a fragment at $m / z 284$, therefore indicating that the methoxy group occurs at position $4^{\prime}$ [66] (Supplement 1, Slide 7). As flavonoids commonly occur as $O$-glycosides and $O$-glycosylation occurs at position 7 in flavanones [63,69], compound (7) was tentatively assigned to naringenin-4'-methoxy-7-pyranoside.

The main compound (8) in the HPLC chromatogram at Rt 16.8 min (Figure 3) gave a $[\mathrm{M}-\mathrm{H}]^{-}$ molecular ion at $m / z 625$ (Table 2). The main fragmentation product ion at $m / z 301$ in the MS and $\mathrm{MS}^{3}$ chromatograms indicated the loss of two glucose molecules ([M-H $\left.]^{-}-2 \times 162 \mathrm{Da}\right)$ as well the presence of a quercetin aglycone moiety corresponding to $m / z 301$ [68] (Supplement 1, Slide 8). Since glucose is usually $\beta$-glycosidically linked to the flavonoid aglycone and $O$-glycosidic linking is usually occurring at position 7 on the A ring of flavonoids [69], compound (8) was tentatively identified as quercetin-7- $\beta$-O-diglucoside.

Compound (9) at Rt 18.2 min (Figure 3b), gave a [M-H] $]^{-}$molecular ion at $\mathrm{m} / z 633$ (Table 2). MS/MS fragmentation resulted in a loss of a fragment product ion at $m / z 481$, corresponding to [M-galloyl-gallic acid. Other fragment product ions resulting from $\mathrm{MS}^{2}$ were; 463 [M-gallic acid] ${ }^{-}$, 300 (hexahydroxydiphenoyl-H) and 169 corresponding to gallic acid [45,70,71] (Supplement 1, Slide 9). Consequently, compound (9) is suggested to be a derivative of corilagin.

Compound (10) at Rt 18.4 min (Figure $3 b$ ) gave a [M-H] $]^{-}$molecular ion at $m / z 585$ (Figure 3, Table 2). MS ${ }^{2}$ fragmentation of this compound resulted in the loss of a pyranose sugar corresponding to the fragment ion at $\mathrm{m} / z 132$ and a galloyl unit corresponding to a fragment ion of $\mathrm{m} / \mathrm{z} 153$. Moreover, a fragment product ion at $m / z 301\left\{[\mathrm{M}-\mathrm{H}]^{-}-132-153\right\}$ (Table 2), corresponding to the aglycone 
of quercetin, was present in the $\mathrm{MS}^{2}$ chromatogram [68] (Supplement 1, Slide 10). Consequently, compound (10) was tentatively assigned to be quercetin 7-O-galloyl-glucoside.

A polyphenol (Compound 11) with a retention time of $19.1 \mathrm{~min}$ in HPLC-DAD (Figure 3b) gave a molecular ion at $m / z$ 725. In the MS ${ }^{2}$ spectrum, the fragment ions of a hexose sugar were observed at $m / z 665$ and 503 , indicating that the cleavage within this hexose sugar ring occurred at ${ }_{0.3} \mathrm{X}$ $[\mathrm{M}-\mathrm{H}-61]^{-}[63,69]$. Moreover, the loss of two oxygen molecules was noticed at $\mathrm{MS}^{3}[\mathrm{M}-\mathrm{H}-2 \times 16]^{-}$. In the spectra at MS ${ }^{4}$, two fragments at $m / z 391$ and 379 were observed. These fragments resulted from the loss of one molecule of water and two methyl groups, respectively, from the fragment at $\mathrm{m} / z 409$ in spectra $\mathrm{MS}^{3}\left([\mathrm{M}-\mathrm{H}]^{-}-\mathrm{H}_{2} \mathrm{O}-2 \mathrm{CH}_{3}\right]^{-}$(Supplement 1 , Slide 11). Thus, compound (11) is suggested to be identical to an unknown ellagitannin that we have reported earlier to occur in T. brownii roots [50].

Compound (12) at Rt 25.5 min (Figure 3b), gave a [M-H] $]^{-}$molecular ion at $\mathrm{m} / \mathrm{z} 343$ (Table 2). $\mathrm{MS}^{3}$ and MS ${ }^{4}$ fragmentation of this compound resulted in the loss of three methyl groups $\left(-\mathrm{CH}_{3}\right)$ corresponding to product fragment ions $\left\{[\mathrm{M}-\mathrm{H}]^{-}\right.$343-328-313\} (Table 2, Supplement 1, Slide 12). Moreover, in the fragment ion chromatogram resulting from $\mathrm{MS}^{3}$, a high intensity of the product fragment ion at $\mathrm{m} / \mathrm{z} 313$ could be observed indicating the loss of a methyl group $\left([\mathrm{M}-\mathrm{H}]^{-}-15\right)$ (Table 2, Supplement 1, Slide 12). From this data, compound (12) was tentatively assigned as 5,6-dihydroxy-3', $4^{\prime}, 7$-trimethoxyflavone.

\section{Discussion}

Pentacyclic triterpene saponins are known to complex with ergosterol and cholesterol in the fungal cell membrane, thus leading to loss of membrane integrity [72] and it has been found that triterpenoids decrease mycelial growth [73]. Accordingly, the triterpenes betulinic acid and arjungenin, isolated from ethyl acetate extracts of $T$. brownii stem bark were found to give good antifungal effects against Aspergillus niger, Fusarium solanii and Fusarium oxysporum with MIC values ranging from 50 to $200 \mu \mathrm{g} / \mathrm{mL}$ [21]. Therefore, we suggest that the two unknown oleanane-type triterpenes (1) and (2) would contribute significantly to the antifungal effects we have found for the ethyl acetate extract of the stem wood of T. brownii (Table 2, Figure 3).

In the genus Terminalia, resveratrol and its glucoside and rutinoside derivatives have been reported in Terminalia prunioides, T. sericea and T. ferdinandiana $[44,74,75]$. We reported here for the first time on the occurrence of the resveratrol derivatives, cis- (3) and trans-resveratrol-3-O- $\beta$-galloylglucoside (4) in Terminalia brownii stem wood. Besides, galloylglucoside derivatives of resveratrol have not been reported before in the genus Terminalia. Resveratrol and its derivatives are antifungal phytoalexins, protecting plants from pathogenic fungal and bacterial intrusion [76,77]. Several investigations on in vitro antifungal activities of resveratrol and its derivatives indicate good antifungal potential of this compound class $[78,79]$. Therefore, the good antifungal activity in the ethyl acetate extracts of T. brownii could partly be due to the resveratrol-galloylglucoside derivatives (2) and (3). To the best of our knowledge resveratrol-3-O- $\beta$-galloylglucoside has not been studied for its antifungal effects, which warrants further studies in this respect.

We reported here for the first time, on the occurrence of another ellagic acid derivative, gallagic acid dilactone (6), in the stem wood of T. brownii. Gallagic acid, is an analogue to ellagic acid, containing four gallic acid residues [80] and has restricted occurrence in plants. Gallagic acid and its derivatives have been found in various parts of some other Terminalia species such as in the leaves of T. catappa and T. oblongata $[65,81]$ and in the fruits of Terminalia bellerica, Terminalia horrida and T. chebula [45]. Gallagic acid is the fully lactonized form of the gallagyl moiety in the ellagitannin punicalagin, which is common in Terminalia spp. [45,82]. Gallagic acid has been found to give concentration-dependent growth-inhibitory effects against Fusarium and Alternaria [83]. Thus, it is possible that gallagic acid dilactone (6), which we found to be present in an ethyl acetate extract of the stem wood of T. brownii, could be an important contributor to the antifungal effects of this extract.

Ellagitannins have been found to inhibit the growth of Fusarium and Alternaria dosedependently [83]. Even though the genus Terminalia is renowned to be especially rich in 
ellagitannins [45] only a few studies have been performed on the antifungal effects of ellagitannins isolated from Terminalia species. Some of the few investigations demonstrate that ellagitannins from Terminalia spp. could be valuable antifungal compounds. For example, punicalagin from the leaf of T. brachystemma was found to give a low MIC value of $6.25 \mu \mathrm{g} / \mathrm{mL}$ against Candida strains [61]. It was found, however, that some ellagitannins were not active against filamentous fungi, although activity was demonstrated against Candida and Cryptococcus neoformans [84]. Thus, it remains to be investigated whether the ellagitannins we have found in T. brownii stem wood, such as methyl-(S)-flavogallonate (5), the unknown ellagitannin (11) and the corilagin derivative (9) give low MIC values against filamentous fungi such as Aspergillus, Nattrassia and Fusarium spp. among others.

Our research resulted in the characterization of the flavonoids naringenin- 4 '-methoxy-7pyranoside (7), quercetin-7- $\beta$-O-diglucoside (8), quercetin-7-O-galloylglycoside (10) and 5,6-dihydroxy3,4,7-trimethoxy flavone (12) in the ethyl acetate extracts of stem wood and bark of Terminalia brownii. To the best of our knowledge this is the first time these flavonoids are reported to occur in T. brownii. We suggest that quercetin-7- $\beta$-O-diglucoside (8), which was quantitatively the main peak in both stem bark and wood extracts of $T$. brownii, contributes significantly to the antifungal effects of these extracts. Accordingly, several authors have reported that quercetin and its derivatives give good antifungal effects against Aspergillus and Fusarium strains [85-87] and for quercetin as low MIC values as $15 \mu \mathrm{g} / \mathrm{mL}$ were recorded against Aspergillus niger, Fusarium moniliforme and F. sporotrichum [88]. Furthermore, dihydroquercetin from barley suppressed the growth of Fusarium spp. [89]. However, it has been demonstrated that quercetin-glycoside was not as antifungal as its aglycone [90]. In contrast to quercetin, some other flavonoids have demonstrated strong antifungal effects as glycosides. For example, naringenin pyranoside demonstrated some antifungal activity with MIC values of 1600-3200 $\mu \mathrm{g} / \mathrm{mL}$ against Candida albicans and C. krusei [91]. Therefore, naringenin-4'-methoxy-7-pyranoside, which we have found in the stem wood of T. brownii, is suggested to give some antifungal activity. Moreover, it has been found that flavonoids possessing methoxy groups are especially antifungal [87]. This would apply to naringenin- $4^{\prime}-$-methoxy-7-pyranoside (7) and 5,6-dihydroxy-3,4,7-trimethoxy flavone (12) which we have found in the stem wood of T. brownii. These flavonoids possess one and three methoxy groups, respectively, and thus are suggested to participate in the antifungal effects of the ethyl acetate extracts of the stem wood of T. brownii.

\section{Materials and Methods}

\subsection{Collection of Plant Material}

The stem wood and stem bark was collected from many individuals of Terminalia brownii growing in natural savannah woodland, in the Blue Nile Forest, in south-eastern Sudan (Figure 1). Voucher specimen were identified by the first author, Mr. Abdelazim Yassin Abdelgadir (Ph.D), Mr. Ashraf Mohamed Ahmed Abd Alla (Ph.D., Wood Sciences) and Mr. Haytham Hashim Gibreel (Ph.D., Taxonomy) at the Faculty of Forestry, University of Khartoum, Sudan and Mr. El Sheikh Abd alla Al Sheikh (Ph.D., Taxonomy) at Soba Forest Research Center, Khartoum, Sudan (Ph.D., Taxonomy). The Voucher specimens are deposited in the herbarium at the Department of Forest Products and Industries, Faculty of Forestry, University of Khartoum, Sudan.

\subsection{Extraction}

Hundred (100) grams of the dried and powdered stem wood and bark were used for the extractions. Extraction was initiated with sequential extraction, beginning with petroleum ether, followed by chloroform and finally the marc was extracted using $80 \%$ methanol. The $80 \%$ methanolic extract was subjected to liquid/liquid fractionation using ethyl acetate and this fractionation resulted in aqueous and ethyl acetate fractions. 


\subsection{Thin Layer Chromatography (TLC)}

Using micro-capillary pipettes, $5 \mu \mathrm{L}$ of ethyl acetate extracts $(5 \mathrm{mg} / \mathrm{mL})$ of the stem bark and wood of T. brownii were applied on normal phase silica gel thin layer plates (Kieselgel 60 F254, aluminum backed, Merck, Darmstadt, Germany) and on reversed phase thin layer plates (RP-18 F254s, Merck, Darmstadt, Germany) to detect compounds of a wide range of polarities. Toluene: ethyl acetate: formic acid (4:5:1, v:v:v) was used as an eluent for NP-TLC, while methanol: water: acetic acid (6:2:2) was used for RP-TLC. The development distance was $8 \mathrm{~cm}$. The plates were sprayed with Vanillin- $\mathrm{H}_{2} \mathrm{SO}_{4}$, Dragendorff reagent, aluminum chloride and Natural Products reagents to detect various compound classes such as essential oils, terpenes, phenolic compounds, alkaloids and flavonoids [57]. The plates were observed in UV-light at 254 and $366 \mathrm{~nm}$. A Camaq Video documentation system was used for photographing the plates.

\subsection{Solid Phase Extraction (SPE)}

LC-18 reversed phase cartridges (Supelco, Sigma-Aldrich, Darmstadt, Germany) were used for solid phase extraction in order to purify and enrich flavonoids and for separation of sugars and other interfering matrix compounds. The columns were equilibrated with $100 \%$ water and elution was performed using a gradient from $100 \%$ to $50 \%$ water followed by $100 \%$ methanol.

\subsection{Reversed Phase High Performance Liquid Chromatography Coupled to Diode Array Detection (HPLC-UV/DAD)}

The Agilent 1100 series HPLC system was used for the HPLC runs. The system consisted of an Agilent 1100 autosampler connected to Agilent series 1200 binary pump system coupled to an Agilent series 1100 thermostatic column compartment and an Agilent series 1100 DAD detector. Separations were performed on a reversed phase column (Varian LC-18; $4.6 \mathrm{~mm} \times 250 \mathrm{~mm}$; ID $5 \mu \mathrm{m}$, USA) at $30^{\circ} \mathrm{C}$ and the flow rate was $0.5 \mathrm{~mL} / \mathrm{min} .5 \mu \mathrm{L}$ of samples $(5 \mathrm{mg} / \mathrm{mL}$ in $80 \%$ aqueous methanol) were injected. Gradient elution was performed using solvent (A) water $+1 \%$ of acetic acid to increase peak resolution. Solvent (B) 100\% acetonitrile. The step gradient began with $90 \%$ A and stopped while reaching $10 \%$ B in $30 \mathrm{~min}$. After this $100 \%$ B was used for $5 \mathrm{~min}$ followed by $10 \%$ B for $5 \mathrm{~min}$. Wavelengths of 254, 320, 360 and $380 \mathrm{~nm}$ were used for detection. The data was compared to standard compounds and computer libraries of pure compounds.

\subsection{LC-Triple Quadrupole Mass Spectrometric Analysis (LC-MS and LC-MS/MS Tandem Mass Spectrometry)}

An HPLC apparatus (1100 series, Agilent, Waldbronn, Germany) connected to an electrospray ionization (ESI) triple quadruple mass spectrometer (HTC Ultra-Bruker Daltonics-Advanced Mass Spectrometry Instrumentation, Germany) was used. Gradient elution was performed using acetonitrile (MeCN) and water containing $0.005 \%$ formic acid (Solvent A) and acetonitrile and glacial acetic acid (Solvent B). A linear gradient from 4\% to 33\% B was employed for $35 \mathrm{~min}$ and was increased to $100 \%$ B for $5 \mathrm{~min}$. Then $4 \% \mathrm{~B}$ was used for $5 \mathrm{~min}$ to re-equilibrate. Mass analysis of compounds was performed using negative ion mode. The spray voltage was set to $5000 \mathrm{~V}$ and the capillary temperature to $+280{ }^{\circ} \mathrm{C}$. Nitrogen was used as sheathing gas and the flow was set to $40 \mathrm{U}$. Collision-induced dissociation (CID-MSn) was applied to induce fragmentation of the molecular ions, and their fragments were analyzed using tandem mass spectrometry. Helium was used as collision gas at $0.8 \mathrm{~m}$ Torr. Collision energies of 15 and $30 \mathrm{eV}$ were used to investigate neutral loss and product ions and scanning was performed using a mass range from 50 to $1000 \mathrm{~m} / \mathrm{z}$. Data from the literature, the Wiley Natural product library, and authentic samples were used for the structural identifications of phenolic compounds such as flavonoids, stilbenes and ellagic acid derivatives as well as triterpenes. 


\subsection{Antifungal Assays}

\subsubsection{Fungal Strains}

Aspergillus niger ATCC 9763, Nattrassia mangiferae ATCC 96293, Aspergillus flavus ATCC 9763 and Fusarium moniliforme ATCC 24378 were obtained from National Research Center, Sudan. Before use, the strains were sub-cultured on Sabouraud dextrose agar (Oxoid ${ }^{\mathrm{TM}} \mathrm{CM} 0041 \mathrm{~B}$ ) slants, at $+35^{\circ} \mathrm{C}$.

\subsubsection{Agar Well Diffusion Method}

A cup well agar diffusion method $[55,56]$ with minor modifications was used. Before the test, the fungal strains were grown on petri dishes $(\varnothing=9 \mathrm{~cm})$ containing Sabouraud dextrose agar at $+35{ }^{\circ} \mathrm{C}$ overnight [92]. The resulting fungal growth was washed with $100 \mathrm{~mL}$ sterile normal saline to obtain fungal suspension containing conidia, which were used for the tests. $200 \mu \mathrm{L}$ of this fungal suspension was adjusted to $1.0 \times 10^{8} \mathrm{CFU} / \mathrm{mL}$ and mixed with $20 \mathrm{~mL}$ of sterile, molten Sabouraud dextrose agar which was poured into sterile petri dishes $(\varnothing=9 \mathrm{~cm})$. The petri dishes were left to set at room temperature. Four holes were cut in the agar using a sterile cork borer (10 $\mathrm{mm}$ in diameter) and each hole was filled with $100 \mu \mathrm{L}$ of extracts $(1 \mathrm{mg} / \mathrm{mL}$ in $50 \%$ methanol) and amphotericin B (Sigma-Aldrich, $1 \mathrm{mg} / \mathrm{mL}$ in $50 \%$ methanol). $100 \mu \mathrm{L}$ of $50 \%$ methanol was used as a negative control. The extracts/antibiotics/solvents were left to diffuse into the agar in the cold room $\left(+4{ }^{\circ} \mathrm{C}\right)$ for one hour. The plates were then incubated at $+35{ }^{\circ} \mathrm{C}$ for $24 \mathrm{~h}$. For each experiment four replicates $(n=4)$ were used. The diameters of the zones of inhibition (IZ) were measured in mm using a caliper and the mean of five diameters \pm SD and SEM was calculated.

\subsubsection{Agar Dilution Method}

Minimum inhibitory concentrations were determined using a slightly modified agar macrodilution method [93]. Fungal conidial suspensions were grown for four days in Sabouraud dextrose broth at $+35^{\circ} \mathrm{C}$. For the test, $1 \mathrm{~mL}$ of these suspensions were diluted with $0.9 \%(w / v) \mathrm{NaCl}$ to contain $1.0 \times 10^{6} \mathrm{CFU} / \mathrm{mL}$. $100 \mu \mathrm{L}$ of these fungal suspensions were mixed with $10 \mathrm{~mL}$ molten Sabouraud dextrose agar which was pipetted into a petri dish $(\varnothing=9 \mathrm{~mm}) .10 \mathrm{~mL}$ of twofold dilutions of plant extracts (from 500 to $31.25 \mu \mathrm{g} / \mathrm{mL}$ ) and amphotericin B (from 500 to $15.625 \mu \mathrm{g} / \mathrm{mL}$ ) were added to the petri dishes. Each dilution contained $500 \mu \mathrm{L}$ of $50 \%$ methanol or hexane solutions of the plant extracts or antibiotics dissolved in $10 \mathrm{~mL}$ of molten Sabouraud dextrose agar. The petri dishes were incubated for $24 \mathrm{~h}$ at $+35^{\circ} \mathrm{C}$. The MIC was taken as those concentrations that resulted in clear petri dishes showing no visible fungal growth. All tests were performed in triplicates. The solvents used for the plant extractions, $50 \%$ methanol or hexane, were used as negative controls. Hexane was used for dissolving those extracts which did not dissolve in $50 \% \mathrm{MeOH}$, that is very nonpolar extracts, such as those originating from hexane and petroleum ether extractions.

\subsubsection{Statistical Analysis}

The Student's $t$-test provided by Microsoft Excel was used for the evaluation of the statistical significance of any differences between the antifungal results of the inhibition zones (IZ) of the tested extracts.

\section{Conclusions}

Ethyl acetate and aqueous extracts of the stem wood and bark of Terminalia brownii give good antifungal effects against Nattrassia mangiferae, Fusarium verticilliodes, Aspergillus flavus and Aspergillus niger. Altogether twelve compounds were identified from an ethyl acetate extract of the stem wood of T. brownii. Cis- and trans-isomers of resveratrol 3-O- $\beta$-galloyl-glucoside were characterized for the first time in this species of Terminalia. Likewise, gallagic acid dilactone has not been reported previously in the stem wood of T. brownii. Owing to its relative chemical stability and its reported 
antifungal efficiency against phytopathogenic molds, gallagic acid dilactone might be an especially interesting component in standardized antifungal extracts of T. brownii. Also, standardized extracts of T. brownii stem wood, enriched with ellagitannins, could be used as natural fungicides for protecting crops and as medicines to treat fungal infections. Ellagitannins purified from these extracts, if found to be more active than the extracts, could be used for ecological crop plant protection and wood preservation, while being relatively stable and possessing less toxicity than synthetic fungicides.

Our results provide partly the justification for the uses of water-based extracts of $T$. brownii for the protection of crop plants and for wood preservation in Africa, although phytochemical analysis of these aqueous extracts would be needed. Further studies are needed on the antifungal activities of separated compounds from both the aqueous and ethyl acetate extracts as well as on various controlled combinations of these compounds. In summary, standardized extracts of T. brownii stem wood could be used as new, cheaper and eco-friendly fungicides for routine use in Africa instead of toxic synthetic fungicides.

Supplementary Materials: The following are available online at www.mdpi.com/2079-6382/6/4/37/s1, (Slides 1-12): Tandem mass spectra of molecular ions and their fragment product ions resulting from selected compounds in a T. brownii ethyl acetate extract of the wood.

Acknowledgments: The first author is grateful for the financial support for this research article by University of Khartoum, Sudan. We would also like to thank Nickoli Kuhnert and his group, School of Engineering and Science, International University, Bremen, Germany for providing LC-MS/MS research facilities.

Author Contributions: Enass Y. A. Salih, performed the data collections, extractions, antifungal analysis, and preliminary chemical identifications and wrote the draft manuscript. Hiba A. Ali, managed the study and provided support in analytical chemistry. Pia Fyhrquist has given a major contribution for the drafting of this manuscript. Other authors, Abdelazim Y. Abdelgadir, Mustafa K. M Fahmi, Mai H. Alamin and Ashraf M. Ahmed were also involved in drafting the final manuscript. All authors have thoroughly revised the paper, read and approved the final manuscript.

Conflicts of Interest: The authors declare no conflict of interest. The founding sponsors had no role in the design of the study; in the collection, analyses, or interpretation of data; in the writing of the manuscript, and in the decision to publish the results.

\section{References}

1. Klemptner, L.R.; Sherwood, J.S.; Tugizimana, F.; Dubery, I.A.; Piater, L.A. Ergosterol, an orphan fungal microbe-associated molecular pattern (MAMP). Mol. Plant Pathol. 2014, 15, 747-761. [CrossRef] [PubMed]

2. Anderson, P.K.; Cunningham, A.A.; Patel, N.G.; Morales, F.J.; Epstein, P.R.; Daszak, P. Emerging infectious diseases of plants: Pathogen pollution, climate change and agrotechnology drivers. Trends Ecol. Evol. 2004, 19, 535-544. [CrossRef] [PubMed]

3. Kieren, A.M.; Thomas, P.; David, D. Aspergillosis: Pathogenesis, clinical manifestations, and therapy. Infect. Dis. Clin. N. Am. 2002, 16, 875-894.

4. Walsh, T.J.; Anaissie, E.J.; Denning, D.W.; Herbrecht, R.; Kontoyiannis, D.P.; Marr, K.A.; Morrison, V.A.; Segal, B.H.; Steinbach, W.J.; Stevens, D.A.; et al. Treatment of Aspergillosis: Clinical Practice Guidelines of the Infectious Diseases Society of America. Clin. Infect. Dis. 2008, 46, 327-360. [CrossRef] [PubMed]

5. Baddley, J.W. Clinical risk factors for invasive aspergillosis. Med. Mycol. 2011, 49, S7-S12. [CrossRef] [PubMed]

6. De Aguirre, L.D.; Hurst, S.F.; Choi, J.S.; Shin, J.H.; Hinrikson, H.P.; Morrison, C.J. Rapid Differentiation of Aspergillus Species from Other Medically Important Opportunistic Molds and Yeasts by PCR-Enzyme Immunoassay. J. Clin. Microbiol. 2004, 42, 3495-3504. [CrossRef] [PubMed]

7. Hadrich, I.; Makni, F.; Ayadi, A.; Ranque, S. Microsatellite Typing to Trace Aspergillus flavus Infections in a Hematology Unit. J. Clin. Microbiol. 2010, 48, 2396-2401. [CrossRef] [PubMed]

8. Dagenais, T.R.T.; Keller, N.P. Pathogenesis of Aspergillus fumigatus in Invasive Aspergillosis. Clin. Microbiol. Rev. 2009, 22, 447-465. [CrossRef] [PubMed]

9. U.S. Department of Health and Human Services. Guidelines for Research Involving Recombinant DNA Molecules; U.S. Department of Health and Human Services: Washington, DC, USA, 1986. 
10. International Agency for Research on Cancer (Iarc). IARC Monograph on the Evaluation of Carcinogenic Risk of Chemicals to Humans; Aflatoxins; International Agency for Research on Cancer: Lyon, France, 1987; Suppl 7, pp. 83-87.

11. Fountain, J.C.; Scully, B.T.; Ni, X.; Kemerait, R.C.; Lee, R.D.; Chen, Z.Y.; Guo, B. Environmental influences on maize-Aspergillus flavus interactions and aflatoxin production. Front. Microbiol. 2014, 5. [CrossRef] [PubMed]

12. Gourama, H.; Bullerman, L.B. Aspergillus flavus and Aspergillus parasiticus: Aflatoxigenic Fungi of concern in Foods and Feeds. J. Food Prot. 1995, 12, 1395-1404. [CrossRef]

13. Willinger, B.; Kopetzky, G.; Harm, F.; Apfalter, P.; Makristathis, A.; Berer, A.; Bankier, A.; Winkle, S. CASE REPORTS Disseminated Infection with Nattrassia mangiferae in an Immunosuppressed Patient. J. Clin. Microbiol. 2004, 42, 478-480. [CrossRef] [PubMed]

14. Sigler, L.; Summerbell, R.C.; Poole, L.; Wieden, M.; Sutton, D.A.; Rinaldi, M.G.; Aguirre, M.; Estes, G.W.; Galgiani, J.N. Invasive Nattrassia mangiferae Infections: Case Report, Literature Review, and Therapeutic and Taxonomic Appraisal. J. Clin. Microbiol. 1997, 35, 433-440. [PubMed]

15. Frankel, D.H.; Rippon, J.W. Hendersonula toruloidea infection in man. Index cases in the non-endemic North American host, and a review of the literature. Mycopathologia 1989, 105, 175-186. [CrossRef] [PubMed]

16. Atanasova-Penichon, V.; Bernillon, S.; Marchegay, G.; Lornac, A.; Pinson-Gadais, L.; Ponts, N.; Zehraoui, E.; Barreau, C.; Richard-Forget, F. Bioguided Isolation, Characterization, and Biotransformation by Fusarium verticillioides of Maize Kernel Compounds that Inhibit Fumonisin Production. Mol. Plant Microbe Interact. 2014, 27, 1148-1158. [CrossRef] [PubMed]

17. Xing, F.; Hua, H.; Selvaraj, J.N.; Yuan, Y.; Zhao, Y.; Zhou, L.; Liu, Y. Degradation of fumonisin B1 by cinnamon essential oil. Food Control 2014, 38, 37-40. [CrossRef]

18. Dornbusch, H.J.; Buzina, W.; Summerbell, R.C.; Lass-Flörl, C.; Lackner, H.; Schwinger, W.; Sovinz, P.; Urban, C. Fusarium verticillioides abscess of the nasal septum in an immunosuppressed child: Case report and identification of the morphologically atypical fungal strain. J. Clin. Microbiol. 2005, 43, 1998-2001. [CrossRef] [PubMed]

19. Da Silva Bomfim, N.; Nakassugi, L.P.; Oliveira, J.F.P.; Kohiyama, C.Y.; Mossini, S.A.G.; Grespan, R.; Nerilo, S.B.; Mallmann, C.A.; Filho, B.A.A.; Machinski, M. Antifungal activity and inhibition of fumonisin production by Rosmarinus officinalis L. essential oil in Fusarium verticillioides (Sacc.) Nirenberg. Food Chem. 2015, 166, 330-336. [CrossRef] [PubMed]

20. Dias, M.C. Phytotoxicity: An Overview of the Physiological Responses of Plants Exposed to Fungicides. Jpn. J. Bot. 2012, 4. [CrossRef]

21. Opiyo, S.A.; Manguro, L.O.A.; Owuor, P.O.; Ochieng, C.O.; Ateka, E.M.; Lemmen, P. Antimicrobial Compounds from Terminalia brownii against Sweet Potato Pathogens. J. Nat. Prod. 2011, 1, 116-120. [CrossRef]

22. Chung, W.H.; Chung, W.C.; Ting, P.F.; Ru, C.C.; Huang, H.C.; Huang, J.W. Nature of Resistance to Methyl Benzimidazole Carbamate Fungicides in Fusarium oxysporum f.sp. lilii and F. oxysporum f.sp. gladioli in Taiwan. J. Phytopathol. 2009, 157, 742-747. [CrossRef]

23. Villa, F.; Cappitelli, F.; Cortesi, P.; Kunova, A. Fungal Biofilms: Targets for the Development of Novel Strategies in Plant Disease Management. Front. Microbiol. 2017, 8. [CrossRef] [PubMed]

24. Mazu, T.K.; Bricker, B.A.; Flores-Rozas, H.; Ablordeppey, S.Y. The Mechanistic Targets of Antifungal Agents: An Overview. Mini Rev. Med. Chem. 2016, 16, 555-578. [CrossRef] [PubMed]

25. Troskie, A.M.; de Beer, A.; Vosloo, J.A.; Jacobs, K.; Rautenbach, M. Inhibition of agronomically relevant fungal phytopathogens by tyrocidines, cyclic antimicrobial peptides isolated from Bacillus aneurinolyticus. Microbiology 2014, 160, 2089-2101. [CrossRef] [PubMed]

26. Martinez, J.A. Natural Fungicides obtained from Plants. In Fungicides for Plant and Animal Diseases; Dhanasekaran, D., Thajuddin, N., Panneerselvam, A., Eds.; InTech: Croatia, Balkans, 2012; pp. 1-28, ISBN 978-953-307-804-5. Available online: https:/ / cdn.intechopen.com/pdfs-wm/26021.pdf (accessed on 1 May 2017).

27. Singh, A.K.; Kumar, P.; Nidhi, R.; Gade, R.M. Allelopathy-A Sustainable Alternative and Eco-Friendly Tool for Plant Disease Management. Plant Dis. Sci. 2012, 7, 127-134.

28. Rodrigues, A.M.; Theodoro, P.N.; Eparvier, V.; Basset, C.; Silva, M.R.; Beauchêne, J.; Espíndola, L.S.; Stien, D. Search for Antifungal Compounds from the Wood of Durable Tropical Trees. J. Nat. Prod. 2010, 73, 1706-1707. [CrossRef] [PubMed]

29. Gupta, S.; Dikshit, A.K. Biopesticides: An eco-friendly approach for pest control. J. Biopestic. 2010, 3, $186-188$. 
30. Shinde, S.L.; Wadje, S.S. Efficacy of terminalia bark extracts against seed-borne pathogens checked by paper disc method. Res. J. Pharm. Biol. Chem. Sci. 2011, 2, 602-607.

31. Valsaraj, R.; Pushpangadan, P.; Smitt, U.W.; Adsersen, A.; Christensen, S.; Sittie, A.; Nyman, U.; Nielsen, C.; Olsen, C.E. New Anti-HIV-1, Antimalarial, and Antifungal Compounds from Terminalia bellerica. J. Nat. Prod. 1997, 60, 739-742. [CrossRef] [PubMed]

32. Wickens, G.E. Flora of Tropical East Africa: Combretaceae; East African Community: Arusha, East Africa's Tanzania, 1973; p. 99.

33. Nguyen, D.-M.-C.; Seo, D.-J.; Park, R.-D.; Lee, B.-J.; Jung, W.-J. Chitosan beads combined with Terminalia nigrovenulosa bark enhance suppressive activity to Fusarium solani. Ind. Crop Prod. 2013, 50, 462-467. [CrossRef]

34. Samie, A.; Mashau, F. Antifungal activities of fifteen Southern African medicinal plants against five Fusarium species. J. Med. Plants Res. 2013, 7, 1839-1848.

35. Fabry, W.; Okemo, P.; Ansorg, R. Fungistatic and fungicidal activity of East African medicinal plants. Mycoses 1996, 39, 67-70. [CrossRef] [PubMed]

36. Baba-Moussa, F.; Akpagana, K.; Bouchet, P. Antifungal activities of seven West African Combretaceae used in traditional medicine. J. Ethnopharmacol. 1999, 66, 335-338. [CrossRef]

37. Nguyen, D.-M.-C.; Seo, D.-J.; Lee, H.B.; Kim, I.S.; Kim, K.Y.; Park, R.D.; Jung, W.J. Antifungal activity of gallic acid purified from Terminalia nigrovenulosa bark against Fusarium solani. Microb. Pathog. 2013, 56, 8-15. [CrossRef] [PubMed]

38. Eldeen, I.M.S.; Van Staaden, J. Antimycobacterial activity of some trees used in South African traditional medicine. S. Afr. J. Bot. 2007, 73, 248-251. [CrossRef]

39. Eldeen, I.M.S.; Elgorashi, E.E.; Mulholland, D.A.; Van Staden, J. Anolignan B: A bioactive compound from the roots of Terminalia sericea. J. Ethnopharmacol. 2005, 103, 135-138. [CrossRef] [PubMed]

40. Conrad, J.; Vogler, B.; Reeb, S.; Klaiber, I.; Roos, G.; Vasquiez, E.; Setzer, M.C.; Kraus, W. Isoterchebulin and 4,6-O-isoterchebuloyl-D-glucose, novel hydrolysable tannins from Terminalia macroptera. J. Nat. Prod. 2001, 64, 294-299. [CrossRef] [PubMed]

41. Conrad, J.; Vogler, B.; Klaiber, I.; Roos, G.; Walter, U.; Kraus, W. Two triterpene esters from Terminalia macroptera bark. Phytochemistry 1998, 48, 647-650. [CrossRef]

42. Silva, O.; Duarte, A.; Pimentel, M.; Viegas, S.; Barroso, H.; Machado, J.; Pires, I.; Cabrita, J.; Gomes, E. Antimicrobial activity of Terminalia macroptera root. J. Ethnopharmacol. 1997, 57, 203-207. [CrossRef]

43. Kuete, V.; Tabopda, T.K.; Ngameni, B.; Nana, F.; Tshikalange, T.E.; Ngadjui, B.T. Antimycobacterial, antibacterial and antifungal activities of Terminalia superba (Combretaceae). S. Afr. J. Bot. 2010, 76, 125-131. [CrossRef]

44. Joseph, C.C.; Moshi, M.J.; Innocent, E.; Nkunya, M.H.H. Isolation of a stilbene glycoside and other constituents of Terminalia sericeae. Afr. J. Tradit. Complement. Altern. Med. 2007, 4, 383-386. [CrossRef] [PubMed]

45. Pfundstein, B.; El Desouky, S.K.; Hull, W.E.; Haubner, R.; Erben, G.; Owen, R.W. Polyphenolic compounds in the fruits of Egyptian medicinal plants (Terminalia bellerica, Terminalia chebula and Terminalia horrida): Characterization, quantitation and determination of antioxidant capacities. Phytochemistry 2010, 71, 1132-1148. [CrossRef] [PubMed]

46. Schmidt, L.H. Terminalia brownii Fresen. Seed Leafl. 2010, 148, 363-374.

47. Mosango, D.M. Terminalia brownii. In Plant Resources of Tropical Africa 11(2): Medicinal plants 2; Schmelzer, G.H., Gurib-Fakim, A., Eds.; PROTA Foundation: Wageningen, The Netherlands, 2013; pp. 245-248.

48. Shuping, D.S.S.; Eloff, J.N. The use of plants to protect plants and food against fungal pathogens: A review. Afr. J. Tradit. Complement. (Ajtcam) 2017, 14, 120-127. [CrossRef] [PubMed]

49. Machumi, F.; Midiwo, J.O.O.; Jacob, M.R.; Khan, S.I.; Tekwani, B.L.; Zhang, H.; Walker, L.A.; Muhaamed, L. Phytochemical, antimicrobial and antiplasmodial investigation of Terminalia brownii. J. Nat. Prod. Commun. 2013, 8, 761-764.

50. Salih, E.Y.A.; Kanninen, M.; Sipi, M.; Luukkanen, O.; Hiltunen, R.; Vuorela, H.; Julkunen-Tiitto, R.; Fyhrquist, P. Tannins, flavonoids and stilbenes in extracts of African savanna woodland trees Terminalia brownii, Terminalia laxiflora and Anogeissus leiocarpus showing promising antibacterial potential. S. Afr. J. Bot. 2017, 108, 370-386. [CrossRef] 
51. Yamauchi, K.; Mitsunaga, T.; Muddathir, A.M. Screening for melanogenesis-controlled agents using Sudanese medicinal plants and identification of active compounds in the methanol extract of Terminalia brownii. J. Wood Sci. 2016, 62, 285-293. [CrossRef]

52. Negishi, H.; Maoka, T.; Njelekela, M.; Yasui, N.; Juman, S.; Mtabaji, J.; Miki, T.; Nara, Y.; Yamori, Y.; Ikeda, K. New chromone derivative terminalianone from African plant Terminalia brownii Fresen (Combretaceae) in Tanzania. J. Asian Nat. Prod. Res. 2011, 13, 281-283. [CrossRef] [PubMed]

53. Mbwambo, Z.H.; Moshi, M.J.; Masimba, P.J.; Kapingu, M.C.; Nondo, R.S. Antimicrobial activity and brine shrimp toxicity of extracts of Terminalia brownii roots and stem. BMC Complement. Altern. Med. 2007, 7, 1-5. [CrossRef] [PubMed]

54. Masoko, P.; Picard, J.; Eloff, J.N. Antifungal activities of six South African Terminalia Species (Combretaceae). J. Ethnopharmacol. 2005, 99, 301-308. [CrossRef] [PubMed]

55. Elegami, A.A.; El-Nima, E.I.; El Tohami, M.S.; Muddathir, A.K. Antimicrobial activity of some species of the family Combretaceae. Phytother. Res. 2002, 16, 555-561. [CrossRef] [PubMed]

56. Kavanagh, F. Analytical Microbiology, 2nd ed.; Academic Press: New York, NY, USA, 1972; p. 11.

57. Wagner, H.; Bladt, S. Plant Drug Analysis: A Thin Layer Chromatography Atlas, 2nd ed.; Springer: New York, NY, USA, 1996; 320p.

58. Stecher, G.; Huck, C.; Popp, M.; Bonn, G.K. Determination of flavonoids and stilbenes in red wine and related biological products by HPLC and HPLC-ESI-MS-MS. J. Anal. Chem. 2001, 371, 73-80. [CrossRef]

59. Otto, A.; Simoneit, B.R.; Wilde, V.; Kuntzmann, L.; Púttmann, W. Terpenoids Composition of three fossil resins from Cretaceae and tertiary Conifers. Rev. Palaeobatony Palynol. 2002, 120, 203-215. [CrossRef]

60. Van der Doelen, G.A.; van den Berg, K.J.; Boon, J.J.; Shibayama, N.; De La Rie, E.R.; Genuit, W.J.L. Analysis of fresh triterpenoid resin and aged triterpenoid varnishes by HPLC. APCI.MS/MS. J. Chromatogr. A 1998, 809, 21-37. [CrossRef]

61. Liu, M.; Katerere, D.R.; Gray, A.I.; Seidel, V. Phytochemical and antifungal studies on Terminalia mollis and Terminalia brachystemma. Fitoterapia 2009, 80, 369-373. [CrossRef] [PubMed]

62. Xia, B.; Bai, L.; Li, X.; Xiong, J.; Xu, P.; Xue, M. Structural analysis of metabolites of asiatic acid and its analogue madecassic acid in zebrafish using LC/IT-MSn. Molecules 2015, 20, 3001-3019. [CrossRef] [PubMed]

63. Pinheiro, P.F.; Justino, G.C. Structural analysis of flavonoids and related compounds-a review of spectroscopic applications. In Phytochemicals-A Global Perspective of Their Role in Nutrition and Health; InTech: Croatia, Balkans, 2012; pp. 1-26.

64. Marzouk, M.S.; El-Toumy, S.A.; Moharram, F.A. Pharmacologically active ellagitannins from Terminalia myriocarpa. Planta Med. 2002, 68, 523-527. [CrossRef] [PubMed]

65. Oeirichs, P.B.; Pearce, C.M.; Zhu, J.; Filippich, L.J. Isolation and structure determination of terminalin A toxic condense tannin from Terminalia oblongata. Nat. Toxins 1994, 2, 144-150. [CrossRef]

66. Canedo, E.M.; Fill, T.P.; Pereira-Filho, E.R.; Rodrigues-Filho, E. Enzymatic Potential of Mucor inaequisporus for Naringin Biotransformation, Accessed by Fractional Factorial Design and Mass Spectrometry Analysis. J. Anal. Bioanal. Tech. 2014, S6. [CrossRef]

67. Lee, M.K.; Bok, S.H.; Jeong, T.S.; Moon, S.S.; Lee, S.E.; Park, Y.B.; Choi, M.S. Supplementation of naringenin and it is synthetics derivatives altars antioxidant enzyme activities of erythrocyte and liver high cholesterol-fed rats. Bioorg. Med. Chem. 2002, 10, 2239-2244. [CrossRef]

68. Fabre, N.; Rustan, I.; de Hoffmann, E.; Quetin-Leclercq, J. Determination of Flavone, Flavonol, and Flavanone Aglycones by Negative Ion Liquid Chromatography Electrospray Ion Trap Mass Spectrometry. J. Am. Soc. Mass Spectrom. 2001, 12, 707-715. [CrossRef]

69. Cuyckens, F.; Claeys, M. Mass spectrometry in the structural analysis of flavonoids. J. Mass Spectrom. 2004, 39, 1-15. [CrossRef] [PubMed]

70. Nuengchamnong, N.; Ingkaninan, K. An on-line LC-MS/DPPH approach towards the quality control of antioxidative ingredients in Sahastara. Songklanakarin J. Sci. Technol. 2017, 39, 123-129. [CrossRef]

71. Xiao, H.-T.; Tsang, S.-W.; Qin, H.-Y.; Choi, F.F.; Yang, Z.-J.; Han, Q.-B.; Chen, H.-B.; Xu, H.-X.; Shen, H.; $\mathrm{Lu}$, A.-P.; et al. A bioactivity-guided study on the anti-diarrheal activity of Polygonum chinense Linn. J. Ethnopharmacol. 2013, 149, 499-505. [CrossRef] [PubMed]

72. Morrissey, J.P.; Osbourn, A.E. Fungal resistance to plant antibiotics as a mechanism of pathogenesis. Microbiol. Mol. Biol. Rev. 1999, 63, 708-724. [PubMed] 
73. Smaili, A.; Mazoir, N.; Aicha Rifai, L.; Koussa, T.; Makroum, K.; Benharref, A.; Faize, L.; Alburquerque, N.; Burgos, L.; Belfaiza, M.; et al. Antimicrobial Activity of two Semisynthetic Triterpene Derivatives from Euphorbia officinarum Latex against Fungal and Bacterial Phytopathogens. Nat. Prod. Commun. 2017, 12, 331-336.

74. Sirdaarta, J.; Matthews, B.; Cock, I.E. Kakadu plum fruit extracts inhibit growth of the bacterial triggers of rheumatoid arthritis: Identification of stilbene and tannin components. J. Funct. Food 2015, 17, 610-620. [CrossRef]

75. Cock, I.E.; van Vuuren, S.F. Anti-Proteus activity of some South African medicinal plants: Their potential for the prevention of rheumatoid arthritis. Inflammopharmacology 2014, 22, 23-36. [CrossRef] [PubMed]

76. Sebastià, N.; Montoro, A.; León, Z.; Soriano, J.M. Searching trans-resveratrol in fruits and vegetables: A preliminary screening. J. Food Sci. Technol. 2017, 54, 842-845. [CrossRef] [PubMed]

77. Zainal, N.; Chang, C.-P.; Cheng, Y.-L.; Wu, Y.-W.; Anderson, R.; Wan, S.-W.; Chen, C.-L.; Ho, T.-S.; AbuBakar, S.; Lin, Y.S. Resveratrol treatment reveals a novel role for HMGB1 in regulation of the type 1 interferon response in dengue virus infection. Sci. Rep. UK 2017, 7, 42998. [CrossRef] [PubMed]

78. Caruso, F.; Mendoza, L.; Castro, P.; Cotoras, M.; Aguirre, M.; Matsuhiro, B.; Isaacs, M.; Rossi, M.; Viglianti, A.; Antonioletti, R. Antifungal Activity of Resveratrol against Botrytiscinerea Is Improved Using 2-Furyl Derivatives. PLoS ONE 2011, 6, 1-10. [CrossRef] [PubMed]

79. Jung, H.J.; Hwang, I.A.; Sung, W.S.; Kang, H.; Kang, B.S.; Seu, Y.B.; Lee, D.G. Fungicidal effect of resveratrol on human infectious fungi. Arch. Pharm. Res. 2005, 28, 557-560. [CrossRef] [PubMed]

80. Crozier, A.; Jaganath, I.B.; Clifford, M.N. Phenols, Polyphenols and Tannins: An Overview. In Plant Secondary Metabolites: Occurrence, Structure and Role in the Human Diet, 1st ed.; Crozier, A., Clifford, M.N., Ahihara, H., Eds.; Blackwell Publishing: Oxford, UK, 2006; pp. 1-25.

81. Silva, L.P.; de Angelis, C.D.; Bonamin, F.; Kushima, H.; Mininel, F.J.; dos Santos, L.C.; Delella, F.K.; Felisbino, S.L.; Vilegas, W.; da Rocha, L.R.M.; et al. Terminalia catappa L.: A medicinal plant from the Caribbean pharmacopeia with anti-Helicobacter pylori and antiulcer action in experimental rodent models. J. Ethnopharmacol. 2015, 159, 285-295. [CrossRef] [PubMed]

82. Cerdá, B.; Cerón, J.J.; Tomás-Barberán, F.A.; Espín, J.C. Repeated oral administration of high doses of the pomegranate ellagitannin punicalagin to rats for 37 days is not toxic. J. Agric. Food Chem. 2003, 51, 3493-3501. [CrossRef] [PubMed]

83. Glazer, I.; Masaphy, S.; Marciano, P.; Bar-Ilan, I.; Holland, D.; Kerem, Z.; Amir, R. Partial identification of antifungal compounds from Punica granatum peel extracts. J. Agric. Food Chem. 2012, 60, 4841-4848. [CrossRef] [PubMed]

84. Latté, K.P.; Kolodziej, H. Antifungal effects of hydrolysable tannins and related compounds on dermatophyte, mould fungi and yeasts. Z. Naturforsch. 2000, 55c, 467-472.

85. Alves, C.T.; Ferreira, I.C.; Barros, L.; Silva, S.; Azeredo, J.; Henriques, M. Antifungal activity of phenolic compounds identified in flowers from North Eastern Portugal against Candida species. Future Microbiol. 2014, 9, 139-146. [CrossRef] [PubMed]

86. Tempesti, T.C.; Alvarez, M.G.; de Arau'jo, M.F.; Ju'nior, F.E.; de Carvalho, M.G.; Durantini, E.N. Antifungal activity of a novel quercetin derivative bearing a trifluoromethyl group on Candida albicans. Med. Chem. Res. 2012, 21, 2217-2222. [CrossRef]

87. Weidenbörner, M.; Hindorf, H.; Jha, H.C.; Tsotsonos, P. Antifungal activity of flavonoids against storage fungi of the genus Aspergillus. Phytochemistry 1990, 29, 1103-1105. [CrossRef]

88. Céspedes, C.L.; Salazar, J.R.; Ariza-Castolo, A.; Yamaguchi, L.; Avila, J.G.; Aqueveque, P.; Kubo, I.; Alarcón, J. Biopesticides from plants: Calceolaria integrifolia sl. Environ. Res. 2014, 132, 391-406. [CrossRef] [PubMed]

89. Mierziak, J.; Kostyn, K.; Kulma, A. Flavonoids as important molecules of plant interactions with the environment. Molecules 2014, 19, 16240-16265. [CrossRef] [PubMed]

90. Liu, H.; Mou, Y.; Zhao, J.; Wang, J.; Zhou, L.; Wang, M.; Wang, D.; Han, J.; Yu, Z.; Yang, F. Flavonoids from Halostachys caspica and Their Antimicrobial and Antioxidant Activities. Molecules 2010, 15, 7933-7945. [CrossRef] [PubMed]

91. Orhan, D.D.; Özçelik, B.; Özgen, S.; Ergun, F. Antibacterial, antifungal, and antiviral activities of some flavonoids. Microbiol. Res. 2010, 165, 496-504. [CrossRef] [PubMed] 
92. Tokarzewski, S.; Ziółkowska, G.; Nowakiewicz, A. Susceptibility testing of Aspergillus niger strains isolated from poultry to antifungal drugs-a comparative study of the disk diffusion, broth microdilution (M 38-A) and Etest ${ }^{\circledR}$ methods. Pol. J. Vet. Sci. 2012, 15, 125-133. [CrossRef] [PubMed]

93. Guarro, J.; Soler, L.; Rinaldi, M.G. Pathogenicity and antifungal susceptibility of Chaetomium species. EUR J. Clin. Microbiol. 1995, 14, 613-618. [CrossRef]

(C) 2017 by the authors. Licensee MDPI, Basel, Switzerland. This article is an open access article distributed under the terms and conditions of the Creative Commons Attribution (CC BY) license (http://creativecommons.org/licenses/by/4.0/). 